\title{
Breeding of bread wheat for leaf rust resistance in Russia
}

\author{
Elena Gultyaeva \\ All Russian Institute of Plant Protection, 196608 Saint Petersburg, Russia
}

\begin{abstract}
Leaf rust, caused by the fungus Puccinia triticina Erikss., is one of the most common diseases of wheat in Russia. The paper reviews $L \mathrm{r}$ genes diversity in Russian commercial wheat varieties. Two hundred and sixty-four winter and one hundred and forty-three spring wheat varieties indexed by the State Register of Breeding Achievements in 2005-2018 were studied. It was found that among new varieties, as many as $5 \%$ of winter wheat and $30 \%$ of spring wheat possess effective seedling resistance. The wide presence of $\operatorname{Lr} 19$ and $\operatorname{Lr} 9$ genes was detected in the spring wheat. Besides, the high resistance to leaf rust was found in spring wheat varieties with new alien $L r$ genes (originated from Thinopyrum intermedium (Host) Barkworth \& D.R. Dewey and Aegilops speltoides Tausch. Over $40 \%$ of winter wheat varieties have different levels of field resistance as well. The molecular screening revealed three varieties with effective adult plant resistance gene $L r 37$. Other winter wheat varieties include a range of ineffective genes ( $L r 1, L r 3, L r 10, L r 26$, and $L r 34)$, alone or in various combinations.
\end{abstract}

\section{Introduction}

Wheat is an important crop, and leaf rust, caused by the fungus Puccinia triticina Erikss., is one of the most common diseases of wheat in Russia [1]. Main grain production in Russia (about $75 \%$ of the grain-growing area) is concentrated in the North Caucasus, Central Black Soil, Central, Volga, Volga-Vyatka, Ural and West Siberia regions. In the period between 1990 and 2000 severe epidemics of leaf rust were reported for 2-3 times causing 30-35\% of yield loss in the North Caucasian region. Five to 7 epidemics caused $20-30 \%$ of yield loss in the Central and Volga regions. In the Central Black Soil Region, the epidemics occurred up to 4 years in a decade and caused $15-20 \%$ of yield loss. Severe disease development was observed every two years and caused $15-20 \%$ of yield loss in the Volgo-Vyatka and Ural regions [2]. Since 2010, leaf rust incidents have been decreased significantly in all regions of Russia. The depression of the leaf rust development might be caused by climate change and undesirable conditions for pathogen development. Alternatively, a widespread practice of No-Till in arable farming might have caused the spread of other hemibiotroph-induced diseases such as septoriosis and tan spot. Despite the existing environmental problems and common wheat-growing practices, Russian breeders have made a great effort in the design of the rust-resistant varieties. In addition, immunological and genetic protection has contributed to the reduction of leaf rust severity. 
Breeding for resistance to leaf rust has been done for over a half-century in Russia. In 1990-2000 the strategy of deployment of varieties with different bases for resistance involving utilization of major genes, introgression of major genes from wild relatives, alien translocations and slow rusting was adopted in the most of Russian Breeding Centers. This approach denies the domination of a single variety, as occurred in the past period [3].

Since 1995 the All-Russian Institute of Plant Protection (VIZR) has been annually evaluating new varieties for leaf rust resistance. During the same period our laboratory has been conducting seedling resistance studies of common wheat varieties recommended for the cultivation in Russia. We found the increasing number of resistant varieties in 2000 as compared to 1990s. Early studies (before 1995) of 61 winter and 100 spring wheat varieties revealed only $4 \%$ of resistant bread wheat varieties. The similar proportion of bread spring (121) and winter (62) varieties in 2005 showed $1.8 \%$ of winter and $15 \%$ of spring wheat varieties resistant to leaf rust [4].

The State Register of Breeding Achievements permitted to use 264 new varieties of winter wheat and 143 of spring wheat in the period between 2005 and 2018. The paper reviews the studies of Russian commercial wheat varieties for leaf rust resistance and characterises the identification of $L r$-genes.

\section{Materials and methods}

Two hundred and sixty-four winter and one hundred and forty-three spring wheat varieties were used in this study.

Leaf rust infection was evaluated for 4 isolates with different virulence/avirulence combinations at the seedling stage. All isolates were avirulent to $L r 24$ and $L r 29$, and virulent to Thatcher lines (Tc) with Lrl, Lr2b, Lr2c, Lr3a, Lr3bg, Lr3ka, Lr10, Lr14a, $\operatorname{Lr} 14 b, \operatorname{Lr} 18$, and $\operatorname{Lr} 30$. The isolates varied in their virulence to $\operatorname{Lr} 2 a, \operatorname{Lr} 9, \operatorname{Lr} 15, \operatorname{Lr} 16$, $\operatorname{Lr} 19$, Lr20, and Lr26. Ten-fourteen days old seedlings were used in this study. Infection types were recorded according to Mains \& Jackson [5]. Infection type "2" suggested allocation of the seedlings to the resistant group, while infection type " 3 " meant the susceptible group. The molecular markers were used for identification of 20 genes $(L r 1$, Lr3a, Lr9, Lr10, Lr19, Lr20, Lr21, Lr24, Lr25, Lr26, Lr28, Lr29, Lr34, Lr35, Lr37, Lr41, Lr47, Lr51, LrSp, and Lr6Agi 1). [6, https://maswheat.ucdavis.edu].

\section{Results and Discussion}

It was found that among the new varieties, as many as $5 \%$ of winter and $30 \%$ of spring wheat possess seedling resistance. Besides, over $40 \%$ of winter wheat varieties had different levels of field resistance.

Presence of $\operatorname{Lr} 19$ and $\operatorname{Lr} 9$ genes was detected widely in the spring wheat indexed in the State Register and recommended for growing in Russia (Table 1). As many as 7\% of the varieties carried $\operatorname{Lr} 19$ and 9\% carry $\operatorname{Lr} 9$. (Table 2). The first variety L503 with $\operatorname{Lr} 19$ gene was included into the State Register in 1993 and variety Tertsiya with gene $\operatorname{Lr} 9$ in 1995. The effectiveness of $\operatorname{Lr} 19$ and $L r 9$ was lost in the Volga region in the middle of 1990 s and in the Ural and West Siberian regions in 2007, respectively. Our study suggests using a gene combination such as $\operatorname{Lr} 19$ or $\operatorname{Lr} 9$ with $\operatorname{Lr} 26$ to provide high effectiveness to combat virulent isolates of leaf rust. Spring wheat varieties Omskaya 37, Omskaya 38 and Omskaya 41 with genes $L r 19+L r 26$ and variety Silach with genes $L r 9+L r 26$ were highly resistant to the leaf rust at the seedling and the adult plant stages.

Besides, the high resistance to the leaf rust was found in the spring wheat varieties with new alien $L r$ genes. New resistance genes Lr6Agil and Lr6Agi2 from Thinopyrum 
intermedium (Host) Barkworth \& D.R. Dewey were found in varieties Belyanka, Favorit, Lebedushka, Voevoda (Lr6Agil), Tulaikovskaya 5, 10, 100, and Tulaikovskaya zolotistaya (Lr6Agi2). The varieties have been recommended for cultivation in Volga regions. The $L r S p$ gene is not identical to the known effective $L r$ genes. It was transferred from Aegilops speltoides Tausch. and identified in the variety Chelyaba 75. Currently, this variety is recommended for cultivation in the Ural region.

Table 1. Wheat varieties with high or partial effective $L r$ genes

\begin{tabular}{|c|c|c|c|c|c|}
\hline Variety & Year $^{\mathrm{a}}$ & $\begin{array}{c}\text { Region } \\
\mathrm{s}^{\mathrm{b}}\end{array}$ & Variety & Year & Regions \\
\hline \multicolumn{3}{|c|}{ Varieties with gene $L r 9$} & \multicolumn{3}{|c|}{ Varieties with gene $\operatorname{Lr} 19$} \\
\hline Tertsya & 1995 & $\begin{array}{l}\text { WS ES U } \\
\text { NC }\end{array}$ & L $503(+\operatorname{Lr} 10)$ & 1993 & $\begin{array}{l}\text { LV MV } \\
\text { CBS U }\end{array}$ \\
\hline Tuleevskaya & 2002 & WS U & Samsar & 1994 & MV \\
\hline Splav & 2002 & NW & L $505(+\operatorname{Lr} 10)$ & 1996 & LV VV U \\
\hline Duet $(+\operatorname{Lr} 10)$ & 2003 & WS U & Volgouralskaya & 2001 & MV \\
\hline Chelyaba $2(+\operatorname{Lr} 10)$ & 2005 & $\mathrm{U}$ & Dobrunya & 2002 & LV \\
\hline Pamyati Ryuba & 2006 & WS U & Yuliya & 2002 & MV \\
\hline Udacha & 2006 & WS & Ariya & 2004 & $\mathrm{U}$ \\
\hline Nemchinovskaya 24 & 2006 & $\mathrm{C}, \mathrm{VV}$ & Ecada 6 & 2005 & MV \\
\hline Alexandrina & 2007 & WS & Kinelskaya $61(+\operatorname{Lr} 10)$ & 2005 & MV \\
\hline Kinel'skaya otrada & 2009 & MV & Kinelskaya Niva & 2007 & MV U \\
\hline Novosibirskaya 44 & & & Lebedushka $(+$ Lr6Agil $)$ & 2009 & LV \\
\hline$(+\operatorname{Lr} 1, \operatorname{Lr} 10)$ & 2009 & Ws & Omskaya $37(+\operatorname{Lr} 26)$ & 2009 & WS \\
\hline Sibakovskaya yubileinaya & 2010 & & $38(+\operatorname{Lr} 26)$ & 2010 & WS \\
\hline$(+\operatorname{Lr} 1, \operatorname{Lr} 10)$ & 2010 & Ws & Tulaikovskaya 108 (+Lr?) & 2014 & LV U \\
\hline Chelyaba yubileinaya & 2010 & WS & Tulaikovskaya 110 (+Lr?) & 2015 & LV \\
\hline Mariya $1(+\operatorname{Lr} 10)$ & 2011 & WS & Kinelskaya yubileinaya & 2016 & MV U \\
\hline Altayskay $110(+\operatorname{Lr} 10)$ & 2011 & WS & Ulyanovskaya 105 & 2017 & MV U \\
\hline Apasovka $(+L r 10)$ & 2012 & WS & \multicolumn{3}{|c|}{ Varieties with gene Lr6Agi2 } \\
\hline Novosibirskaya $18(+\operatorname{Lr} 10)$ & 2012 & WS ES & \multicolumn{2}{|c|}{ Tulaikovskaya 5 (+Lr10, Lr34, 2001} & MV U \\
\hline Sibirskaya 17 & 2013 & WS & Tulaikovskaya 10 & 2003 & MV VV U \\
\hline Nemchinovskaya 17 & 2013 & $\mathrm{C}$ & Tulaikovskaya zolotistaya & 2006 & MV LV U \\
\hline Sibirskiyi Alyans $(+L r l)$ & 2012 & WS ES & Tulaikovskaya 100 & 2007 & MV \\
\hline Zauralochka $(+\operatorname{Lr} 10)$ & 2014 & WS & \multicolumn{3}{|c|}{ Varieties with gene Lr6Agi1 } \\
\hline Kinelskaya 2010 & 2014 & MV U & Belyanka & 1999 & LV \\
\hline Chelyaba rannaya $(+L r 10)$ & 2016 & $\mathrm{U}$ & Favorit & 2007 & $\begin{array}{l}\text { CBE LV MV } \\
\text { U }\end{array}$ \\
\hline Stolupinskaya $(+\operatorname{Lr} 10)$ & 2017 & WS & Voevoda & 2008 & LV \\
\hline \multicolumn{3}{|c|}{ Varieties with gene $L r S p$} & \multicolumn{3}{|c|}{ Varieties with gene $\operatorname{Lr} 24$} \\
\hline Челяба $75 \overline{(+L r 1, L r 10)}$ & 2012 & $\mathrm{U}$ & $\begin{array}{l}\text { Kanyuk (+1AL/1RS, } L r 20) \\
\text { KBC Akvilon }\end{array}$ & $\begin{array}{l}2016 \\
2013\end{array}$ & $\begin{array}{c}\mathrm{C} \\
\mathrm{C} \mathrm{CBE}\end{array}$ \\
\hline
\end{tabular}

a year of admission for use;

$\mathrm{b}$ regions recommended for cultivation of wheat variety.

Abbreviation of regions: NW - North Western, C - Central, CBS - Central Black Soil, LV Low Volga, MV - Middle Volga, VV - Volga-Vyatka, NC - North Caucasus, U - Ural, WS West Siberia, ES - East Siberia.

Thus, $20 \%$ of spring wheat varieties with seedling resistance carry highly or partially effective major genes and indexed by the State Register. One-third of the varieties carries effective $L r$ genes, however, they are not identical to those registered in the Catalogue.

Winter wheat varieties demonstrated the various responses to leaf rust within wheatgrowing region. More than half of the studied varieties originated from North-Caucasian 
breeding program. They showed a certain level of resistance at the adult plant stage under the field conditions.

Table 2. Distribution of $L r$ genes in Russian bread wheat varieties (\%)

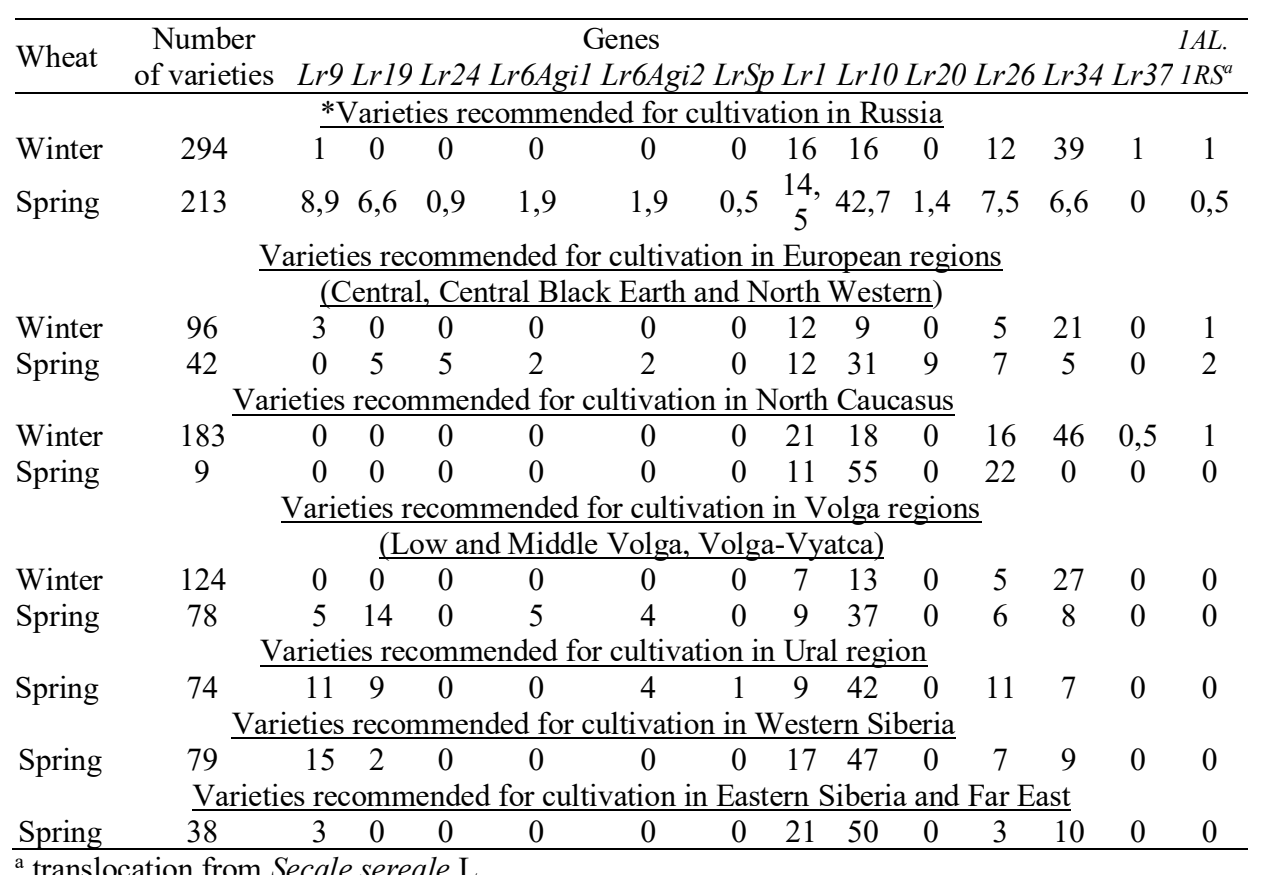

a translocation from Secale sereale $\mathrm{L}$.

The molecular screening revealed as many as three varieties (Morozko, Graf, Svarog) with an effective adult plant resistance gene $L r 37$. In Russia other winter wheat varieties carry the wide range of ineffective genes, namely $L r 1, L r 3, L r 10, L r 26$ and $L r 34$ (Table 2). They have either a single gene or various genes combinations. Probably the resistance of these varieties at the adult plant stage is provided by a combination of minor genes.

And though development of resistant varieties using different combinations of racespecific $L r$ genes is challenged by completely or partial loss of their effectiveness, there is still a worldwide interest to this approach. Creation of varieties with the different combinations of $L r$ genes increases the chances to improve the genetic protection of wheat and limits the overcoming wheat resistance. Monitoring of the rust population has been performed across the country and there are reliable data on the structure on the pathogen population and effectiveness of $L r$ genes. In particular, it has been found that the virulence genes of the leaf rust population differs remarkably in West Siberia when compared to the European regions of Russia, as confirmed by phenotypic and molecular analyses. This phenomenon may be largely explained by the high diversity of wheat varieties grown under different climate conditions linked to the usage of a wide range of donors of resistance.

The current research was partially supported by RFBR grant No. 19-016-00052. 


\section{References}

1. S.S. Sanin, Plant Protection News [Vestnik Zashchity Rasteniy]. 1, 3-14 (2010)

2. S.S. Sanin, L.N. Nazarova, E.A. Sokolova, T.Z. Ibragimov Zashita i karantin rastenii. 2, 28 (1999)

3. A. Morgounov, I.B. Ablova, L. Babayants, O. Babayants, L. Bespalova, Zh. Khudokormova, N. Litvinenko, V. Shamanin, V. Syukov. Euphytica. 179, 297 (2011)

4. E.I. Gultyaeva. Russian Agricultural Sciences. 38, 125 (2012)

5. E.B. Mains, H.S. Jackson, Phytopathology. 16, 89 (1926)

6. L. Błaszczyk, I.Kramer, F. Ordon, J. Chełkowski, M. Tyrka, J. Vida, I. Karsai Cereal Research Communications 36, 201 (2008) 